\title{
Determinants of Worldwide Software Piracy
}

\author{
Zlatko J. Kovačić \\ The Open Polytechnic of New Zealand, Wellington, \\ New Zealand
}

Zlatko.Kovacic@openpolytechnic.ac.nz

\begin{abstract}
Software piracy or 'softlifting', the unauthorized use or illegal copying of computer software seems to be a persistent and truly global phenomenon, in spite of international efforts to reduce it. Could the battle against it be won by just merely accepting international standards for the protection of intellectual property rights? The answer to this question is the main focus of this research. This paper explores the determinants of cross-national variation in software piracy rates by performing a quantitative analysis using economic, cultural and legal variables. Based on regression analysis results, we identified factors which have a significant impact on software piracy. Among them, economic and legal factors make the most important contribution to the variability of worldwide software piracy rates. The implications of these results both for practice and theory are discussed.
\end{abstract}

Keywords: Software piracy, national culture, economic factors, law enforcement, intellectual property rights

\section{Introduction}

Software piracy or 'softlifting', the unauthorized use or illegal copying of computer software seems to be a persistent and truly a global phenomenon in spite of international efforts to reduce it. The widespread of the Internet and communication technologies in the last decade created an infrastructure which makes sharing digital products (software, music and video products) easier than ever before. Consequently this has increased the opportunity for further escalation of intellectual property rights (IPRs hereafter) violation. Copyright violation and software piracy are causing huge losses worldwide. The Business Software Alliance (BSA) estimated an increase of $4.8 \%$ in 2005 to $\$ 34.3$ billion of worldwide direct losses due to software piracy (BSA, 2006). The good news is that more countries achieved reduction in piracy than those where an increase was recorded. Although, the absolute revenue losses due to software piracy increased, the growth was slower than the general market growth (5\% and 7\% respectively). According to BSA curbing the piracy in countries with high piracy rates could be attributed also to their awareness of IPR issues and their permanent effort to impose IPRs protection.

Material published as part of this publication, either on-line or in print, is copyrighted by the Informing Science Institute. Permission to make digital or paper copy of part or all of these works for personal or classroom use is granted without fee provided that the copies are not made or distributed for profit or commercial advantage AND that copies 1) bear this notice in full and 2) give the full citation on the first page. It is permissible to abstract these works so long as credit is given. To copy in all other cases or to republish or to post on a server or to redistribute to lists requires specific permission and payment of a fee. Contact Publisher@InformingScience.org to request redistribution permission.
Due to the BSA methodology piracy losses data are based on business software applications (consumer software applications excluded) and members' companies' information only and could be considered as direct losses. However, losses due to piracy are not only direct but could also be indirect and could occur in both developed and developing 
countries. Therefore we would say that BSA data on losses due to software piracy are a conservative estimate, the lower boundary of true, unknown losses due to software piracy. Software companies have direct losses due to illegal distribution and use of their products, which reducing resources they would otherwise invest in further software development. Consequently that would have an impact on employment and wages in software industry. On the other side, countries with high software piracy rates usually have lower level of IPRs protection which has serious consequences on their economic development. First, governments will have losses due to the reduced tax revenues. Second, foreign investors might be unwilling to invest in countries with a high level of intellectual property investment risk. As a result that could slow down foreign investment in the host country. As Javorcik (2004) illustrated in case of transition economics of Eastern Europe, lower level of IPRs protection could cause investors in sectors relying heavily on the protection of intellectual property to be discouraged from investing in such a host country. There is also weak evidence that all investors might be discouraged to invest in these countries. These are some of the reasons to study determinants of software piracy phenomenon.

In most literature on software piracy only the negative effects, i.e. losses due to the software piracy were considered. However, software piracy could have some positive effects on countries with a high piracy rate. A more balanced approach of the analysis of software piracy costs and benefits was presented in Wooley \& Eining (2006) who gave an overview of factors that have impact on software piracy, discussing their positive and negative effects. In an attempt to answer the question: Is piracy always bad? Givon, Mahajan \& Muller (1995) estimated lost sales in software industry due to software piracy and its impact on software diffusion. They suggested that pirates may influence potential users to adopt software, and that some of these adopters may eventually purchase the software. They even claimed that in United Kingdom the pirates helped significantly in legal penetration of spreadsheet and word-processing software. We would also advocate a more balanced and holistic approach which takes into account not just measurable economic effects (for example, losses due to software piracy) but also non-economic, and long run effects that may bring a positive overall benefit for countries and even for the software companies involved. We can speculate that perhaps this was the reasoning and idea behind the decision of the big IT players such as Yahoo and Google and other software companies who invested in China on a grand scale, despite the high piracy rate and piracy losses in that region.

The main objective of this study is to explain the variation in worldwide software piracy rates. More specifically the data gathered for the paper was used to address the following question: what is the relative importance of each factor in the model of worldwide software piracy? Before answering this question a brief overview of the previous empirical studies of piracy is given. Then in the following section the main groups of factors are discussed together with the hypotheses. The data and methodology section describes definition and data source as well as the statistics and econometrics methods used in this study. The final section reports the results and discusses the implications of these results.

\section{Literature Overview}

Software piracy research can be conducted at two levels: individual and country-national. Initially, the focus in the software piracy research was at individual level.

\section{Software Piracy Research Overview - An Individual Level}

A number of researchers have attempted to identify individuals' intentions, attitudes and moral propensity toward piracy and factors that might impact their decision to be involved in such illegal activity. Cheng, Sims \& Teegen (1997) identified two factors: software price and household income as significant. They suggested that a higher software price might cause potential buyers to buy pirated copies. Also, by pricing software according to buyers' household income a further 
reduction in their piracy intention might be expected. Rasmussen (2003) considered an economic model which incorporates network externalities to explain software piracy and appropriate firm's strategy to deal with it. He also suggested what would be an optimal level of software protection for a firm. Dealing with the similar problem Altinkemer \& Guan (2003) used game theory to analyze software firms' protection strategies for online software distribution. The effect of cost structure on buyer purchase intention was a focus of Nunes, Hsee \& Weber (2004) research paper. They have shown that buyers are less willing to pay for information products with relatively low variable cost and high fixed cost.

Gopal \& Sanders (1998) found that gender, age, ethical predisposition and ethical propensity were related to software piracy behavior. Peace \& Galletta (1996) developed a predictive model of software piracy behavior based on the theory of planned behavior, expected utility theory and deterrence theory confirming that the first theory was a good fit to data. Limayem, Khalifa \& Chin (2004) used the Triandis' cultural model as a conceptual framework to measure factors that have an impact on software piracy intention and actual behavior. They found that social factors and perceived consequences were influential while affect did not have a significant influence on intention to pirate software. An opposite conclusion was reached by Al-Rafee \& Cronan (2006), i.e. affect was found to be a stronger predictor of attitude as well as Machiavellianism, age and subjective norms. Glass \& Wood (1996) used equity theory to identify effects of situational factors on the intentions of individuals to participate in software piracy. They concluded that their approach is more fruitful than a study based on an ethical decision. However, Gupta, Gould \& Pola (2004) found that ethics as a factor is embedded in a set of factors (attitudes, legal aspects, social support, perception of economic loss and age) which have impact on software piracy.

A population of college students was the most used population in software piracy studies (see for example: Cronan, Foltz \& Jones, 2006; Gan \& Koh, 2006; Hunduja, 2003; Sims, Cheng \& Teegen, 1996). Besides being easily "accessible" for researchers, i.e. academic staff undertaking a survey, the other reason might be that they are more prone and open to behavior which leads toward software piracy. Furthermore, Woolley \& Eining (2006) found that not much has been changed in software piracy rates among accounting students since 1991, when they conducted similar research, despite their increasing knowledge of copyright laws. However, Simmons (2004) thinks that students are not the real problem in piracy, but the firms who can afford to purchase the original and still buying the pirated copies. Liang \& Yan (2005) provide the most comprehensive review of software piracy among college students in the last 30 years suggesting the technical, legal and educational strategies that deal with college students' software piracy.

\section{Software Piracy Research Overview - A Cross-National Level}

In this paper the second approach to software piracy research based on cross-national data was adopted. The summary of the software piracy research using cross-national data in the last decade is given in Appendix. Five groups of factors influencing the software piracy were identified: economic, cultural, socio-political, technological and legal factors. Initially focus in cross-national research was the economic factors, but it was realized that these factors alone were unable to explain all the variations in the software piracy rates.

\section{Economical factors}

One of the first and most frequently used factors used to explain variation in software piracy rates between countries. The following list gives some of the main economic variables considered in software piracy research: gross domestic product (GDP) per capita, domestic market size, unemployment, expenditure on research \& development in country's GDP, foreign direct investments and market/economic freedom. For the full list of economic variables see the column in the Appendix labeled as "Independent variables". The main finding in most studies summarized in the 
Appendix is that economic factors are significant on their own, but when other factors such as cultural and legal are included the results are not so conclusive. Only in one case no relationship between GDP and piracy rates was found (Hogenbirk \& van Kranenburg, 2001). The different impact of the real GDP per capita on the piracy rate was detected in countries with lower levels of income than in wealthier countries. Gopal \& Sanders $(1998,2000)$ suggested that $\$ 6,000$ is the inflection point that separates these two groups of countries. The effect of GDP on piracy rate is more pronounced in countries with less than $\$ 6,000$ GDP per capita.

Beside real GDP per capita significance of other economic factors were identified in case of R\&D investment rates (Ginarte \& Park, 1997), income inequality (Husted, 2000; Ki, Chang, \& Khang, 2006), expenditure on R\&D (Marron \& Steel, 2000), share of export of goods and services and high technology exports (Hogenbirk \& van Kranenburg, 2001), expected profit (Papadopoulos, 2003), state tax burden (Bezman \& Depken, 2004), inflation rate (Depken \& Simmons, 2004) and IT expenditure (Kyper Lievano, Mangiameli, \& Shin, 2004). More complete list of findings related to economic factors is presented in the Appendix.

\section{Cultural factors}

Equivalently to the approach at individual level, where the ethics and personal attitude toward piracy constructs were included, at the country level different cultural construct(s) which describe what attitude people in a particular country or certain culture milieu have toward intellectual property rights, ownership and protection were included. Simmons (2004, p. 140) describes the differences between Western and Asian cultural approaches to the intellectual property rights, emphasizing that individual creative development among Westerners has individual ownership, while in Asian culture "creators are obliged by their place in society to share their developments and improve the society as a whole". The well-known Hofstede's cultural model (Hofstede, 1980, $1981,1983,2004$ ) was the most frequently used cultural moidel in software piracy research (see for example, Bagchi, Kirs, \& Cerveny, 2006; Depken \& Simmons, 2004; Husted, 2000; Ki et al., 2006; Kyper et al., 2004; Moores, 2003; Ronkainen \& Guerrero-Cusumano, 2001; Shin, Gopal, Sanders, \& Whinston, 2004). The results related to the cultural factors are inconclusive though the same set of Hofstede's cultural constructs was used. The most frequently used variable was individualism/collectivism. All studies which included at least one of Hofstede's cultural constructs used this variable. Only in one case this variable was not identified as significant (Ki et al., 2006). In half of the studies other Hofstede's cultural constructs were included, but only on a single occasion these variables (masculinity and uncertainty avoidance indices) were significant (Ronkainen \& Guerrero-Cusumano, 2001 and Bagchi et al., 2006, respectively). Power distance index was found to be weakly significant on two occasions. However, when the model without GDP was estimated in two subsets of data, power distance index was not significant (Kyper et al., 2004). The same happened when the education level (literacy rate) was included (Depken \& Simmons, 2004). The same authors found the interaction between individualism and power distance has a positive sign and significant impact on the piracy rate.

\section{Socio-political factors}

This group of factors comprises wide spectra of variables including education, openness, globalization, democracy and corruption. Well-known indices such as political right index, country openness index, democracy index, i.e. political rights and civil liberties measured by Freedom House index, corruption measured by Transparency International corruption perception index were used to measure these socio-political concepts. In general, the evidence of relationship between software piracy rates and various socio-political indices is rather weak. Marron \& Steel (2000) found the education to be weakly related to piracy rate when controlling for economic, cultural and institutional factors. Using literacy rate as an indicator of the country's educational level Depken \& Simmons (2004) have not identified a significant relationship between education 
and piracy rate. The same conclusion was reached by Ginarte \& Park (1997) by using secondary school enrolment data. Impact of the country openness was quite weak as Yang \& Maskus (1998) research suggested, while Ginarte \& Park (1997) found the link to be strong, but only for poorer half of the countries.

Ginarte \& Park (1997, p. 298) described why democracy is not important factor in explaining variation in piracy rates: "Countries which have political freedom (but little market freedom) end up losing political freedom due to slow growth in living standards. Likewise, countries which have market freedom (but little political freedom) end up acquiring greater political freedom due to a rise in living standards. Thus, it is market freedom, and not so much political freedom, that provides an environment conductive to innovation and production" Indeed, the data did not confirm democracy as a significant factor (Ginarte \& Park, 1997; Andrés, 2003). The corruption was the only factor from socio-political group identified as significant in all studies that included this variable in the software piracy model (Ronkainen \& Guerrero-Cusumano, 2001; Papadopoulos, 2003; Bagchi et al., 2006).

\section{Technological factors}

Technological factors, including IT infrastructure and Internet diffusion in particular, were considered as potential explanatory variables in the software piracy rate models. When technological factors were included in the model the following indicators were used to measure IT infrastructure and Internet diffusion: number of Internet service providers, TVs, phones, PCs and Internet users per 1,000 persons. The rationale behind using these variables in the piracy models is that the more PC and Internet users are in a country the less likely pirated software will be used due to the network and scale effects which would make the software more affordable.

The main finding is that technological factors, when included, were not significant (Bagchi et al., 2006), mixed results were obtained when PC and TV penetration variables were included (Hogenbirk \& van Kranenburg, 2001), while Bezman \& Depken (2005) found that piracy rate and the number of Internet users are inversely related. When the global software piracy is disaggregated on piracy of products in the multimedia, entertainment and software industry high density of TVs positively influenced the motion picture piracy rate, while penetration of PCs was not significant in any of these industries (van Kranenburg \& Hogenbirk, 2005). The same results were obtained when the revenue losses due to piracy was used as a dependent variable.

\section{Legal factors}

Legal system and regulations in domain of IPRs protection were identified lately as one of the major contributors to the variations in software piracy rates between countries. Different aspects of the regulations were considered and most frequently the following: trade regulation law related to IT, country's copyright protection system, commitment to protection of IPRs, quality of bureaucracy and rule of law, international copyright convention membership and membership duration, and index of government effectiveness. In most cases these legal factors or variables were set of indicator variables related to the World Trading Organization (WTO) standards and other multilateral, bilateral and unilateral treaties, i.e. dummy variables taking 0 or 1 depending whether country signed or not a particular treaty which protect IPRs.

Although the legal and IPRs protection aspect of the software piracy looks quite straightforward when used in the model, in practice countries accused for the lack of IPRs regulation or for not imposing the law strictly are facing quite difficult dilemma. First, setting the foundation for all legal institutions and infrastructure in domain of IPRs protection could be very daunting and expensive task. It requires resources (Ostergard, 2000) and the officials in these countries should be educated for setting up, implementing and maintaining a system for IPRs protection. Of course there must be also willingness at the country level to accept international standards in IPRs and 
start implementing such protection and an adequate political decision should be made. On the other side, as Rasmussen (2003) noticed the authorities in these (often less-developed or transitory) countries might not be interested in preventing piracy by increasing law enforcement because it will significantly decrease country's welfare. Population and even businesses in these countries heavily depend on the access to relatively cheap software. Therefore the authorities in these countries are trying to find a balance between increasing law enforcement (required by international organizations such as WTO and developed countries) and decreasing country's welfare.

The main finding is that the IPRs protection plays a significant role in all software piracy models where it was in some form included (Yang \& Maskus, 1998; Hogenbirk \& van Kranenburg, 2001; Andrés, 2003; Papadopoulos, 2003). Software protection has significant negative effects, i.e. increasing IPRs protection will result in decreasing software piracy rates. Furthermore, when unilateral, bilateral and multilateral treaties were separately included it was identified that bilateral pressures to protect IPRs stay significant in models controlling for multilateral treaties, GDP and human capital, which suggests that multilateral and bilateral pressures are complementary (Shadelen, Schrank \& Kurtz, 2005).

\section{Software Piracy Research Overview - A Combined Approach}

So far we discussed two approaches to software piracy research: micro and macro, i.e. individual and cross-national. However Holm (2003) suggested testing the same piracy model by using two approaches. First, at the micro or individual level he used a survey among students to identify variables with significant impacts on the software piracy. Economic theory and two demographics variables (gender and age) were identified as such influential variables. Then, in the next step he tested the same model against data at the macro or country's level. Both income and judicial efficiency were identified as highly significant and with the expected signs.

In an exploratory analysis of software piracy using survey data from five countries (two Western and three Asian) Simmons (2004) made an effort to combine and discuss cross-national data of Hofstede's cultural constructs with the attitude towards software piracy data at individual level.

\section{Software Piracy Research Overview - A Methodological Issues}

Differences in the results, i.e. factors' contribution to the variation in the software piracy rates between countries could be attributed to the differences in the data set (size, structure and variables definitions), methods and model specification used. For example, the sample size varied from 13 countries in one region only (Andrés, 2002, 2003) and 24 countries worldwide (Yang \& Maskus, 1998) to as much as 110 countries (Ginarte \& Park, 1997). Availability of data was one of the major restrictions for estimation of the piracy models worldwide, particularly when Hofstede's cultural constructs were included or some of the IPRs protection measures. Having data for limiting number of countries (usually developed countries) often means that there is no much variation in some variables included such as democracy (almost all developed countries are democratic and have the same scores on democracy scale). As a consequence impact of these variables can't be detected or separated from impact of other independent variables in the piracy model. Further that would mean we would make a wrong decision by falsely concluding that this particular factor has no influence on the software piracy.

Including some countries in a worldwide analysis while excluding others could cause a selection bias. For example, including the software piracy rates in the regression analysis would result in the exclusion of more than 113 country's GDP per capita data because only 84 countries have piracy data. Usually more advanced countries with much better developed data collection proce- 
dures would be among included countries. It is not clear how much bias this selection introduces into the results.

In regard to the methods used most of research articles are using regression methods (multiple and stepwise) and models with cross-section and panel data, though there are also attempts to use time series data since the software piracy rates time series are long enough for that kind of analysis (Kyper et al., (2004). Some authors go step forward from the regression analysis and use the path analysis to address an issue of possible direct and indirect dependences between variables (Ki et al., 2006).

Using different constructs for some factors (socio-political in particular) could also generate differences in results. For example besides using Freedom House index to measure democracy we can use Polity IV or Polyarchy, i.e. Vanhanen's Index of Democratization. It is not clear how much bias this selection of variables could introduce into the results. In other words, some of the results might not be robust to changes in variable definition and it is uncertain to what extent these results might vary.

\section{Theoretical Consideration and Hypotheses}

\section{Economic Factor and Hypothesis}

Economic factor was identified at both individual and cross-national level as one of the most important determinant of the software piracy. It is more likely that the individual who can't afford software (due to the low individual or household income) would buy the pirated copy. Possible explanation is that income level can influence the ability of consumers to purchase software, and consequently influenced software piracy attitudes and behaviors. We would expect at the country level that variations in the software piracy rates could be partly explained by variation in the country's GDP per capita. Countries with the higher income tend to have lower software piracy rates, i.e. strong negative relationship between income and piracy rate is expected. However, economic factor and income effect in particular could not be considered as the only important factor. For example high income country such as Greece $(\$ 23,500$, estimated in 2006) has higher software piracy level $(65 \%)$ than country such as South Africa $(\$ 13,000)$ with software piracy rate of $35 \%$. This relationship between country's income and piracy rate could also reflect impact other factors (such as national culture and legal environment) might have on both income and piracy rate. We therefore hypothesize:

Hypothesis H1: More developed countries with high level of economic development tend to have lower software piracy rate (negative relationship).

\section{Cultural Factor and Hypothesis}

Cultural factor could be an important determinant of the software piracy because of the attitude people in a certain culture may have toward piracy, IPRs and their protection. Of course, higher piracy rate in a particular country does not imply that people in that country are less ethical than in the countries with lower piracy rate. According to El Sheikh, Rashed, Qudah, \& Peace (2006) in the Western societies an individualist approach, i.e. the "right of ownership" is a focus which leads toward legal protection of IPRs. On the other side in non-Western societies, benefit of a society as a whole is a focus. However, if those countries with higher piracy rate would like to join the global, international markets than they have to 'play by the rules', i.e. accept business rules of the global business environment and address the IPRs issues as El Sheikh et al. (2006) suggested.

Hofstede cultural model is one of the most frequent cultural models used in empirical cultural studies. By using data from one firm only (IBM, a large multinational firm) Hofstede (1980, 
1983) controlled for a number of industry and company variables so that he could focus on cultural differences. He identified four largely independent dimensions of differences between national value systems: 1) individualism vs. collectivism, 2) power distance, 3) masculinity vs. femininity, and 4) uncertainty avoidance.

The Individualism/Collectivism dimension describes the relationship between individuals and the group in a society. For the countries with low individualism, i.e. high collectivism, people consider the group as the main source of their identity. On the other hand, an individualistic culture would pay more attention to the performance of the individual. Sharing software among group members is considered acceptable and beneficial for the whole group and is expected. We therefore hypothesize:

Hypothesis H2a: Countries with high values of individualism index tend to have a lower software piracy rates (negative relationship)

The Power Distance dimension reflects the perception that members of society have about unequal distribution of power in institutions and organizations and the extent to which it is accepted in a society. People in countries where power distance is large accept a hierarchical order in which everybody has a place that needs no further justification. In these countries if the highly ranked person is involved in some unethical behavior or even illegal activity such as software piracy, subordinates would not questioned or challenged his/her behavior. In other words we would expect that people in countries where power distance is large would at least tolerate software piracy, which means higher software piracy rates in these countries. We therefore hypothesize:

Hypothesis $\boldsymbol{H} 2 \boldsymbol{b}$ : Countries with high value of power distance index tend to have a higher software piracy rate (positive relationship)

The Masculinity/Femininity dimension describes the achievement orientation in a society. When the preferences in society are for achievement, assertiveness, and material success then the country is ranked high on masculinity. On the other side, cultures that rank low on masculinity, i.e. high on femininity, prefer relationships, caring for the weak, and the quality of life. A high masculinity index indicates a culture that emphasizes masculine values and has very separate and rigid gender roles and expectations. However, as Husted (2000) noticed, there is no clear indication about what type of relationship between software piracy and masculinity we can expect. Though it would be incorrect to generalize from the software piracy studies at the individual level we can get some information from these studies about what we can expect. Since the software piracy studies at the individual level identified male participants as more prone toward piracy we may expect at the country's level that higher pirate rate goes with higher masculinity index. This is opposite to Ronkainen \& Guerrero-Cusumano (2001) hypothesis: the higher the masculinity in a country, the less intellectual property violation occurs. They argued that "emphasis on acquisition of material wealth at the expense of caring for others will lead to less violation of others' intellectual property rights". We therefore hypothesize:

Hypothesis H2c: Countries with high values of masculinity index tend to have higher software piracy rates (positive relationship)

The Uncertainty Avoidance dimension describes the degree to which members of a society feel uncomfortable with uncertainty and ambiguity, preferring structured over unstructured situations. Members of societies with strong uncertainty avoidance would tend to avoid or reduce the risk induced by the unknown, i.e. unstructured situation, while people from countries with weak uncertainty avoidance could be described as 'risk takers'. People in these countries would take the risk involved with illegal use of software, while the people in high uncertainty avoidance coun- 
tries would hesitate to buy pirated software because of the risk involved. We therefore hypothesize:

Hypothesis H2d: Countries with high values of uncertainty avoidance index tend to have a lower software piracy rates (negative relationship)

All four dimensions of the Hofstede cultural model were included in the later empirical analysis. However, in the literature not all four dimensions were considered to be relevant for research on the impact of national culture on the software piracy. As we have discussed before only the individualism/collectivism index was included in these models. Quite a few studies we have reviewed included one or all other three dimensions.

\section{Legal Factor and Hypothesis}

Intellectual property rights, protection and legal foundation or lack thereof are considered important determinants of the software piracy. The empirical studies we have summarized in the Appendix have acknowledged the importance of intellectual property protection laws in discouraging piracy. Those countries that signed unilateral, bilateral and multilateral treaties or conventions for IPRs protection and have membership in international organizations for intellectual property rights protections tend to have lower software piracy rates (Ki et al., 2006). Beside statute component of the IPRs protection, the second component, i.e. law enforcement component should be also taken into account when discussing software piracy. We can argue that law enforcement component and how efficient is the judicial system, are even more important than statute component, i.e. the strength of laws in countries with high software piracy rates. Unless the judicial system efficiently prosecutes infringement of the IPRs law the software piracy trend will not curb down as expected. As we discussed before, for the enforcement of these laws, countries must have institutional structures and financial resources, the requirements which quite often are not met. In these countries the fact that IPR is protected by law does not guarantee that the people and even businesses would obey the law unless there is strongest law enforcement. Alternatively, as argued by Ginarte and Park (1997), we can look at the execution of IPR laws, i.e, to examine the complaints against the IPR system (delays in courts, low penalties, and inadequate damages) as a measure of judicial system efficiency. In countries with high level of complains against the IPR system the high level of software piracy will be expected. We therefore hypothesize:

Hypothesis H3: Countries with high values of law enforcement index tend to have lower value of software piracy rates (negative relationship)

\section{Data and Methodology}

\section{Data Definition and Sources}

Data for this paper was collected from four secondary statistical sources at the aggregate countrylevel. Table 1 describes the definition of variables in detail, their acronyms and data sources used. Software piracy rate, as reported by BSA, was examined as a dependent variable with set of three groups of independent variables: economic, cultural and legal factors. To measure economic factor this study utilized GDP per capita in constant U.S. dollars (GDPPC). To measure cultural factor Hofstede's three cultural indices were adopted (PDI, IDV and MAS). Similarly to Shadlen, Schrank \& Kurtz (2005) for obeying the law we utilized the measure of "rule of law" (RULEofLAW) provided by Kaufmann, Kraay \& Mastruzzi (2006).

One of the main restrictions in this kind of analysis is lack of data for all countries. Software piracy rates are available for 84 countries only and cultural constructs for 85 countries, though the GDP per capita is available for 197 countries. When applying regression analysis the data set has been even further reduced to 69 countries only, because the cases were selected listwise. Unfortu- 
Table 1: Description of variables, acronyms and data sources

\begin{tabular}{|l|l|}
\hline \multicolumn{1}{|c|}{ Acronym } & \multicolumn{1}{c|}{ Description, Data Source and Availability } \\
\hline PIRACY & $\begin{array}{l}\text { Piracy rate is the percentage of software installed in country without a licence. } \\
\text { Software pirated is estimated as the difference between software programs in- } \\
\text { stalled (demand side) and software programs legally shipped (supply side). The } \\
\text { piracy rates are defined as the volume of software pirated as a percentage of total } \\
\text { software installed in each country. Piracy rates range from 0\% to 100\% [Source: } \\
\text { BSA (2003, 2004)] Available for } 84 \text { countries in the period 1994-2003. }\end{array}$ \\
\hline GDPPC & $\begin{array}{l}\text { Gross Domestic Product per capita in US dollars in current prices. [Source: } \\
\text { World Bank (2005)] Available for 197 countries. }\end{array}$ \\
\hline IDV & $\begin{array}{l}\text { Individualism is a cultural construct developed by Geert Hofstede and interpreted } \\
\text { as the degree a society reinforces individual or collective achievement and inter- } \\
\text { personal relationships. [Source: Hofstede (2004)] Available for 95 countries. }\end{array}$ \\
\hline PDI & $\begin{array}{l}\text { Power Distance Index is a cultural construct developed by Geert Hofstede and } \\
\text { interpreted as the degree of equality, or inequality, between people in a country's } \\
\text { society. [Source: Hofstede (2004)] Available for 95 countries. }\end{array}$ \\
\hline MAS & $\begin{array}{l}\text { Masculinity is a cultural construct developed by Geert Hofstede and interpreted } \\
\text { as the degree a society reinforces, or does not reinforce, the traditional masculine } \\
\text { work role model of male achievement, control, and power. [Source: Hofstede } \\
\text { (2004)] Available for 95 countries. }\end{array}$ \\
\hline UAI & $\begin{array}{l}\text { Uncertainty Avoidance Index is a cultural construct developed by Geert Hofstede } \\
\text { and interpreted as the extent to which the members of a culture feel threatened by } \\
\text { uncertain or unknown situations, i.e. unstructured situations. [Source: Hofstede } \\
\text { (2004)] Available for 95 countries. }\end{array}$ \\
\hline RULEofLAW & $\begin{array}{l}\text { Rule of Law, i.e. perceptions of the incidence of crime, the effectiveness and pre- } \\
\text { dictability of the judiciary, and the enforceability of contracts (the extent to } \\
\text { which property rights are protected). [Source: Kaufmann et al (2006)] Available } \\
\text { for 199 countries. }\end{array}$ \\
\hline
\end{tabular}

nately, the list of 85 countries for which the Hofstede's indices are available does not match the list of countries for which the software piracy rates data is available.

We considered many other variables of interest suggested in literature, such as corruption (Transparency International corruption perceptions index), democracy (Freedom House index), income inequality (Gini index of the Word Bank), human capital index (United Nations), and high-tech export (World Bank). However, due to the multicolinearity between variables they were found to be statistically insignificant or the models were not statistically acceptable. These results are not presented here. Methodologically this problem of multicolinearity could be analyzed further by using factor analysis or other multivariate methods for data reduction. However, these data reduction techniques were not utilized in this paper.

GDP per capita usually shows non-linear relationship with most considered variables. Therefore, for statistical use, a logarithmic transformation has been applied to GDPPC data to meet the normality assumption. From Figure 1 the scatterplot matrix, i.e. shape of each individual scatterplot indicates that the relationships between variables are linear or nearly linear.

\section{Methodology Used}

Methods of descriptive, correlation and regression analysis were applied to the data. The ordinary least squares (OLS hereafter) method of estimation was used to estimate piracy rates regression models. For statistical analysis we used SPSS for Windows version 13. 


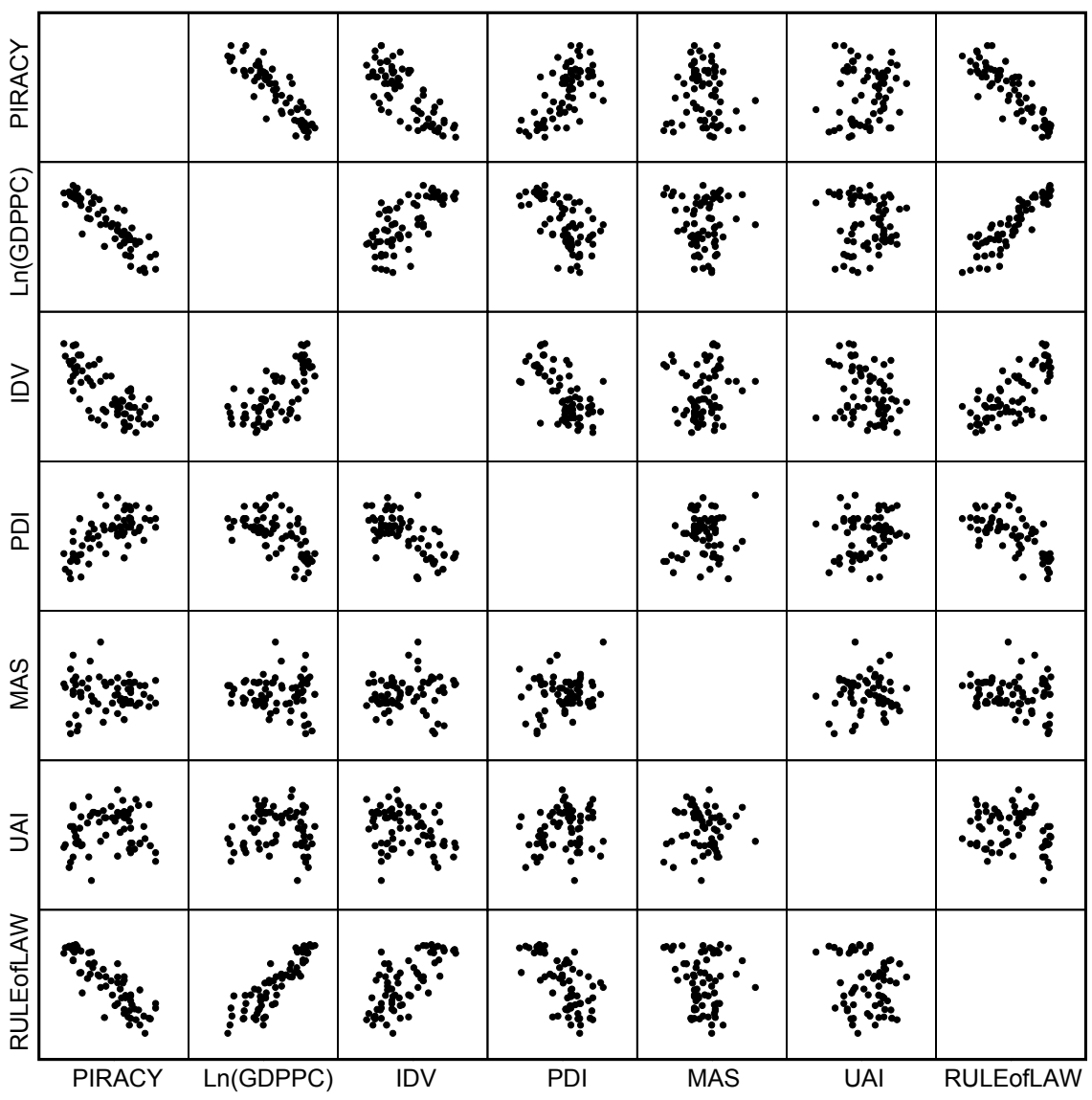

Figure 1: Scatterplot matrix of variables used

\section{Results and Implications}

\section{Descriptive Data Analysis}

Visual inspection of the relationships between variables (see Figure 1 for scatterplots) suggests that PIRACY is linearly and quite strongly related to GDPPC, RULEofLAW and in some extent to cultural variables IDV and PDI. The last cell in the second row of the scatterplot matrix suggests high linear relationship between GDPPC and RULEofLAW, that could cause the problem in the software piracy models where these two variables are included.

In the set of four cultural variables negative relationship was visually identified in case of IDV and PDI which confirms Hofstede's proposition that a collectivist country is also likely to be a high power distance country. And again, from methodological point this result could cause a multicolinearity problem when these two variables are included in the software piracy regression model. Another observation could be made in the set of cultural variables. Namely, a few observations stand apart from the rest of the points in the scatterplot suggesting possible outliers in the data.

Finally, RULEofLAW and GDPPC are positively related to IDV variable (countries with more individualistic culture tend to have efficient laws enforcement and higher level of economic development) and negatively with PDI (countries with higher power distance index tend to have less efficient laws enforcement and lower level of economic development). 


\section{Correlation Analysis}

Table 2 displays above the main diagonal the correlation matrix and below the diagonal the partial correlation matrix for all variables included in this study. According to expectation the correlation matrix shows that the level of economic development (GDPPC) and laws enforcement (RULEofLAW) are negatively related to piracy rates (-0.89 and -0.87 respectively). We also find highly significant positive correlation between the level of economic development and laws enforcement (0.90). Even when controlling for other variables this correlation stay highly significant (partial correlation between GDPPC and RULEofLAW is 0.58). This result is consistent with the general observation that economic development level and the laws enforcement are positively associated. In $\mathrm{H} 1$ we argued that the higher the level of economic development, the more likely countries will have higher software piracy rates. In H3 we argued that the higher the level laws enforcement, the more likely countries will have lower software piracy rates. Both hypotheses were confirmed by using correlation analysis.

Table 2: Correlation matrix (above diagonal) and partial correlation matrix (below diagonal)

\begin{tabular}{|c|c|c|c|c|c|c|c|}
\hline Variable & PIRACY & $\operatorname{Ln}(G D P P C)$ & IDV & PDI & MAS & UAI & RULEofLAW \\
\hline PIRACY & & $-0.89 * * *$ & $-0.77 * * *$ & $0.67 * * *$ & -0.05 & 0.14 & $-0.87 * * *$ \\
\hline $\operatorname{Ln}(G D P P C)$ & $-0.44 * * *$ & & $0.70^{* * *}$ & $-0.59 * * *$ & -0.05 & -0.02 & $0.90^{* * *}$ \\
\hline IDV & $-0.21^{*}$ & 0.10 & & $-0.66^{* * *}$ & 0.10 & $-0.29 * *$ & $0.73 * * *$ \\
\hline PDI & $0.24 *$ & 0.15 & $-0.30^{* *}$ & & 0.14 & 0.19 & $-0.67 * * *$ \\
\hline MAS & $-0.27 * *$ & 0.01 & $0.22 *$ & $0.22 *$ & & -0.03 & -0.14 \\
\hline UAI & 0.02 & $0.37 * *$ & $-0.25 * *$ & -0.02 & -0.04 & & -0.19 \\
\hline RULEofLAW & $-0.27 * *$ & $0.58^{* * *}$ & 0.08 & -0.15 & $-0.30 * *$ & $-0.29 * *$ & \\
\hline
\end{tabular}

Correlation matrix: $N=69$, Partial correlation matrix: $N=63$, * $p<0.10, * * p<0.05, * * * p<0.01$

Within the set of cultural variables IDV was found to have a negative significant correlation coefficient with PIRACY (-0.77), while PDI has a positive correlation coefficient (0.67). The other two cultural variables are found not to be correlated with PIRACY. However, when the controlling for economic development level (GDPPC) and laws enforcement (RULEofLAW) these two cultural variables become only weakly related to PIRACY (significant at $10 \%$ level), but the MAS variable, i.e. its partial correlation coefficient with PIRACY now becomes significant $(-0.27$ at 5\% level). Ronkainen \& Guerrero-Cusumano (2001) also found that masculinity was not significant when taken in isolation. However, it became significant as part of the group of all considered variables. Examining the relationship between piracy and cultural variables in isolation would lead to conclusion that at least two cultural constructs, i.e. Individualism/Collectivism and Power Distance have impact on software piracy. However, when wider set of factors such as economic and legal factors are taken into consideration impact of these two cultural variables on the software piracy become less, but still significant. Thus, $\mathrm{H} 2 \mathrm{a}$ and $\mathrm{H} 2 \mathrm{~b}$ are confirmed, i.e. more individualistic countries have lower software piracy rates while more power distance countries have higher software piracy rates.

$\mathrm{H} 2 \mathrm{c}$ implies significant positive relationship between MAS and PIRACY. The results in Table 2, however, show no clear support for this hypothesis. Simply correlation coefficient between MAS and PIRACY is not significant, but the partial correlation coefficient is significant at $5 \%$ level. 
We also hypothesized that the countries with high values of uncertainty avoidance index tend to have lower software piracy rates. However, the results in Table 2 (both simple and partial correlation coefficients) do not support this and we therefore cannot confirm $\mathrm{H} 2 \mathrm{~d}$.

\section{Regression Analysis}

Table 3 shows the results of the model of ordinary least squares estimations for software piracy rates. We specified four models for software piracy rates. Model 1 includes economic and legal factors measured by GDPPC and RULEofLAW variables, and all four Hofstede's cultural variables. We simplified Model 1 by eliminating insignificant UAI variable, estimated as Model 2. The last two models in Table 3 are estimated software piracy models when one variable at the time were eliminated from the Model 2, GDPPC eliminated in Model 4 and RULEofLAW eliminated in Model 3.

Table 3: Regression results (dependent variable $=$ PIRACY; $\beta$ coefficients; $t$-statistics in brackets)

\begin{tabular}{|c|c|c|c|c|}
\hline Variable & Model 1 & Model 2 & Model 3 & Model 4 \\
\hline GDPPC & $\begin{array}{c}-0.464 * * * \\
(-3.84)\end{array}$ & $\begin{array}{c}-0.455^{* * * *} \\
(-4.14)\end{array}$ & $\begin{array}{c}-0.662 * * * \\
(-9.32)\end{array}$ & - \\
\hline IDV & $\begin{array}{c}-0.134^{*} \\
(-1.65)\end{array}$ & $\begin{array}{c}-0.138^{*} \\
(-1.77)\end{array}$ & $\begin{array}{c}-1.820^{* *} \\
(-2.33)\end{array}$ & $\begin{array}{c}-0.178 * * \\
(-2.05)\end{array}$ \\
\hline PDI & $\begin{array}{c}0.134^{*} \\
(1.94)\end{array}$ & $\begin{array}{c}0.134 * \\
(1.95)\end{array}$ & $\begin{array}{c}0.172 * * \\
(2.49)\end{array}$ & $\begin{array}{c}0.120 \\
(1.56)\end{array}$ \\
\hline MAS & $\begin{array}{c}-0.113^{* *} \\
(-2.19)\end{array}$ & $\begin{array}{c}-0.113^{* *} \\
(-2.21)\end{array}$ & $\begin{array}{l}-0.083 \\
(-1.62)\end{array}$ & $\begin{array}{c}-0.141^{* *} \\
(-2.49)\end{array}$ \\
\hline UAI & $\begin{array}{c}0.010 \\
(0.18)\end{array}$ & 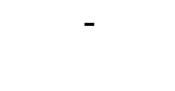 & - & - \\
\hline RULEofLAW & $\begin{array}{c}-0.285 * * \\
(-2.22)\end{array}$ & $\begin{array}{c}-0.292 * * \\
(-2.41)\end{array}$ & - & $\begin{array}{c}-0.685 * * * \\
(-8.09)\end{array}$ \\
\hline$R^{2}$ & 0.860 & 0.860 & 0.847 & 0.821 \\
\hline Adjusted $R^{2}$ & 0.845 & 0.848 & 0.837 & 0.810 \\
\hline$F-$ test & $63.26 * * *$ & $77.09 * * *$ & $88.30 * * *$ & $73.55 * * *$ \\
\hline$J-B$ test & 0.427 & 0.412 & 0.082 & 0.924 \\
\hline
\end{tabular}

The coefficient of determination $R^{2}$ measures the proportion of the variation in the dependent variable "explained" by the regression model. The results reported in Table 3 suggest that in all regression models included variables explained between $82 \%$ and $86 \%$ variation in the software piracy rates. The Jarque-Bera $(J-B)$ test at the bottom of the Table 2 shows that the residuals of each equation satisfy the basic OLS assumption of normality.

The coefficient of GDPPC was found to be negative and significant across all models. The negative coefficient suggests that an increase in the GDPPC results in a significant decline in software piracy rates, and vice versa. These results are consistent with results presented in other empirical piracy studies and confirm the hypothesis H1. The coefficient of RULEofLAW was found to be also negative and significant (at 5\% level) across all models. Again, these results for the legal factor confirm hypothesis $\mathrm{H} 3$ and are consistent with the results in previous software piracy studies. Thus, an efficient laws enforcement system with strong copyright protection generally results in lower piracy rates. Comparing these two coefficients in Model 1 and Model 2 we found that 
economic factor (GDPPC) is relatively more important factor in software piracy models than legal factor (RULEofLAW).

The reason for estimating Model 3 and Model 4 was to see what would be the results of excluding important and significant variables from the software piracy model. Estimated models in the last two columns confirmed theoretical results and our expectation. Impact of excluded variable was attributed to the variables we left in the model. For example, in Model 3 effect of excluded legal factor (RULEofLAW) was allocated to economic and cultural factors, which resulted in increase of their coefficients. In other words, we would make an incorrect conclusion about effect these two factors have on the software piracy rates. The same comment applies to Model 4 where the GDPPC was excluded from the software piracy model.

SPSS for Windows version 13 provides a few colinearity diagnostic tools including tolerance, variance-inflation factor (VIF) and others. All these tools were used, but the results are not reported here. VIF coefficients are high for Model 1 and Model 2 (between 6 and 7 for GDPPC and RULEofLAW). However, since the standard errors of estimates are not so large and the regression coefficients are significant, that would mean we can ignore VIF values and conclude that we have accurately estimated impact of these variables on the software piracy rates.

We also hypothesized that the national culture could have effects on the software piracy. However, the results do not support clearly and strongly the relation between cultural variables and software piracy. Masculinity index (MAS) was found to be significant at 5\% level in Model 1 and Model 2, while Individualism/Collectivism index (IDV) and Power Distance index (PDI) were only weakly significant (at 10\% level). In Model 4, when GDPPC was excluded, PDI was found not to be significant anymore. All coefficients in the models were with expected signs: MAS and PDI positive and IDV negative. Only UAI has different sign from expected, but the coefficient was not significant. Therefore only weakly, but no conclusive evidence was found for the relation between a country's culture and the piracy rate for the countries included in the data set.

\section{Concluding Remarks}

Empirical investigation of relationship between software piracy rates and economic, cultural and legal factors using cross-national data is a main focus of this paper. Correlation analysis detected negative linear relationships between piracy rates and all other variables considered (power distance index being the only exception). According to correlation and regression analyses results economic and legal factors are strong determinants of variation in the software piracy rates worldwide. Countries with high level of economic development and more efficient laws enforcement system will probably have lower software piracy rates. Economic factor seems to be more important than legal factor, contributing more to explanation of variation in software piracy rates. Adding national culture to the list of determinants of worldwide software piracy over $86 \%$ of variation in the software piracy rates can be explained with economic, legal and cultural factors. However, impact of national culture must be interpreted with some caution. Two cultural constructs in Hofstede's cultural model, i.e. individualism and power distance, have only weakly impact of piracy rates, while for masculinity index was found to have positive impact on the piracy rates. In other words, the culture which is described as more masculine would tend to have higher software piracy rate.

The study has some policy implications. For instance, the overview of studies at the micro data level suggests that campaigns aimed at making individuals more ethically concerned about illegal piracy may be more naïve than efficient. The overview of studies at the macro data level and our results suggest that it is difficult to separate issues of piracy from issues of poverty and governance. Our results are consistent with results from other similar studies on software piracy where conclusion was that in spite of efficient legal system (laws enforcement and protection of IPRs) 
full reduction of piracy rate is not possible due to the economic and cultural factors. IPRs protection is a concept strongly affected by cultural values. In case when an IPRs enforcement interfere with the national culture people would tend to stick to their cultural norms rather than to decide to adapt legal norms imposed from outside their groups. Only when national economy reaches certain level of economic development a significant decrease in software piracy rates could be expected.

This study is subject to certain reservations. First, the whole world was considered as homogenous, i.e. regional differences were not considered in this study, but they could have significant impact on the software piracy rates. Second, cross-section data was used. However, the time component should be considered because the relationship between software piracy and its determinants may evolve over time.

\section{References}

Al-Rafee S., \& Cronan, T. P. (2006). Digital piracy: Factors that influence attitude toward behavior. Journal of Business Ethics, 63(3), 237-259.

Altinkemer, K., \& Guan, J. (2003). Analyzing protection strategies for online software distribution. Journal of Electronic Commerce Research, 4(1), 34-48.

Andrés, A. R. (2002). The European software piracy: An empirical application. Economics Working Paper, University of Southern Denmark.

Andrés, A. R. (2003). The relationship between software protection and piracy: Evidence from Europe. Law and Economics 0402001, Economics Working Paper Archive at WUSTL.

Bagchi, K., Kirs, P., \& Cerveny, R. (2006). Global software piracy: Can economic factors alone explain the trend? Communications of the ACM, 49(6), 70-75.

Bezman, T. L., \& Depken, C. A. (2004). Influences on software piracy: Evidence from the various United States. The University of Texas at Arlington, Department of Economics, Working Paper 04-010. Retrieved January 15, 2005 from http://www.uta.edu/depken/P/statepiracy.pdf

Bezman, T. L., \& Depken, C. A. (2005). The impact of software piracy on economic development. The University of Texas at Arlington, Department of Economics, Working Paper 05-002. Retrieved February 15, 2005 from http://www.uta.edu/depken/P/piracyhdi.pdf

BSA. (2003). Eighth annual BSA global software piracy study: Trend in software piracy 1994-2002. Business Software Alliance. Retrieved December 10, 2004, from http://www.bsaa.com.au/downloads/BSA Piracy Booklet.pdf

BSA. (2004). First annual BSA and IDC global software piracy study. Business Software Alliance. Retrieved December 10, 2004, from http://www.bsaa.com.au/downloads/PiracyStudy070704.pdf

BSA. (2006). Third annual BSA and IDC global software piracy study. Business Software Alliance. Retrieved August 10, 2006, from http://www.bsaa.com.au/20052006\%20Global\%20Piracy\%20Study.pdf

Cheng, H. K., Sims, R. R., \& Teegen, H. (1997). To purchase or to pirate software: An empirical study. Journal of Management Information System, 13(4), 49-60.

Cronan, T. P., Foltz, C. B., \& Jones, T. W. (2006). Piracy, computer crime, and IS misuse at the university. Communications of the ACM, 49(6), 85-90.

Depken, C. A., \& Simmons, L. C. (2004). Social construct and the propensity for software piracy. Applied Economics Letters, 11(2), 97-100.

El Sheikh, A., Rashed, A. A., Qudah, B. A., \& Peace, A. G. (2006). An exploratory study of software piracy in Jordan. The Electronic Journal on Information Systems in Developing Countries, 23(4), 1-8.

Gan, L. L., \& Koh, H. C. (2006). An empirical study of software piracy among tertiary institutions in Singapore. Information \& Management, 43, 640-649. 
Ginarte J. C., \& Park, W. G. (1997). Determinants of patent rights: A cross-national study. Research Policy, 26, 283-301.

Givon, M., Mahajan, V., \& Muller, E. (1995). Software piracy: Estimation of lost sales and the impact on software diffusion. Journal of Marketing, 59(1), 29-37.

Glass, R. S., \& Wood, W. A. (1996). Situational determinants of software piracy: An equity theory perspective. Journal of Business Ethics, 15(11), 1189-1198.

Gopal, R. D., \& Sanders, G. L. (1998). International software piracy: An analysis of key issues and impacts. Information Systems Research, 9(4), 380-397.

Gopal, R. D., \& Sanders, G. L. (2000). Global software piracy: You can't get blood out of a turnip. Communications of the ACM, 43(9), 82-89.

Gupta, P. B., Gould, S. J., \& Pola, B. (2004). "To pirate or not to pirate": A comparative study of the ethical versus other influences on the consumer's software acquisition-mode decision. Journal of Business Ethics, 55(3), 255-274.

Hofstede, G. (1980). Culture's consequences: International differences in work-related values. Beverly Hills, California: Sage Publications.

Hofstede, G. (1981). Culture and organizations. International Studies of Management and Organization, 10(4), 15-41.

Hofstede, G. (1983). National cultures in four dimensions - A research-based theory of cultural differences among nations. International Studies of Management and Organization, 13(1-2), 46-74.

Hofstede, G. (2004). Geert Hofstede cultural dimensions. Retrieved November 19, 2004, from http://www.geert-hofstede.com/hofstede dimensions.php

Hogenbirk, A. E., \& van Kranenburg, H. L. (2001). Determinants of multimedia, entertainment, and business software copyright piracy rates and losses: A cross-national study. Mimeo, Department of Organization and Strategy, University of Maastricht.

Holm, H. (2003). Can economic theory explain piracy behaviour? Topics in Economic Analysis \& Policy, $3(1)$, Article 5.

Hunduja, S. (2003). Trends and patterns among online software pirates. Ethics and Information Technology, 5(1), 49-61.

Husted, B. W. (2000). The impact of national culture on software piracy. Journal of Business Ethics, 26(3), 197-211.

Javorcik, B. S. (2004). The composition of foreign direct investment and protection of intellectual property rights: Evidence from transition economies. European Economic Review, 48, 39-62.

Kaufmann, D., Kraay, A., \& Mastruzzi, M. (2006). Governance matters V: Governance indicators for 1996-2005. World Bank Policy Research Working Paper.

Ki, E-J, Chang, E-H., \& Khang, H. (2006). Exploring influential factors on music piracy across countries. Journal of Communication, 56(2), 406-426.

Kyper, E., Lievano, R. J., Mangiameli, P., \& Shin, S. K. (2004). Software piracy: A time-series analysis. Proceedings of the 10th Americas Conference on Information Systems, New York, U.S.A. Retrieved February 15, 2005 http://aisel.isworld.org/pdf.asp?Vpath=AMCIS/2004\&PDFpath=RINTNL011363.pdf

Liang, Z., \& Yan, Z. (2005). Software piracy among college students: A comprehensive review of contributing factors, underlying processes, and tackling strategies. Journal of Educational Computing Reseach, 33(2), 115-140.

Limayem, M., Khalifa, M., \& Chin, W. W. (2004). Factors motivating software piracy: A longitudinal study. IEEE Transactions on Engineering Management, 51(4), 414-425.

Marron, D. B., \& Steel, D. G. (2000). Which countries protect intellectual property? The case of software piracy. Economic Inquiry, 38(2), 159-174. 
Moores, T. T. (2003). The effect of national culture and economic wealth on global software piracy rates. Communication of the ACM, 46(9), 207-215.

Nunes, J. C., Hsee, C. K., \& Weber, E. U. (2004). Why are people so prone to steal software? The effect of cost structure on consumer purchase and payment intentions. Journal of Public Policy \& Marketing, $23(1), 43-53$.

Ostergard, R. L. (2000). The measurement of intellectual property rights protection. Journal of International Business Studies, 31(2), 349-360.

Papadopoulos, T. (2003). Determinants of international sound recording piracy. Economic Bulletin, 6(10), $1-9$.

Peace, A. G., \& Galletta, D. F. (1996). Developing a predictive model of software piracy behaviour: An empirical study. Proceedings of the 17th International Conference on Information Systems, Cleveland, U.S.A., 209-222.

Rasmussen, H. B. (2003). Explaining software piracy. Centre for Economic and Business Research, University of Copenhagen.

Ronkainen, I. A., \& Guerrero-Cusumano, J. L. (2001). Correlates of intellectual property violation. Multinational Business Review, 9(1), 59-65.

Shadlen, K. C., Schrank, A., \& Kurtz, M. J. (2005). The political economy of intellectual property protection: The case of software. International Studies Quarterly, 49, 45-71.

Shin, S. K., Gopal, R. D., Sanders, G. L., \& Whinston, A. B. (2004). Global software piracy revisited: Beyond economics. Communications of the ACM, 47(1), 103-107.

Simmons, L. C. (2004). An exploratory analysis of software piracy using cross-cultural data. International Journal for Technology Management, 28(1), 139-148.

Sims, R. R., Cheng, H. K., \& Teegen, H. (1996). Toward a profile of student software pirates. Journal of Business Ethics, 15(8), 839-849.

van Kranenburg, H., \& Hogenbirk, A. (2005). Multimedia, entertainment, and business software copyright piracy: A cross-national study. Journal of Media Economics, 18(2), 109-129.

Woolley. D. J., \& Eining, M. M. (2006). Software piracy among accounting students: A longitudinal comparison of changes and sensitivity. Journal of Information Systems, 20(1), 49-63.

World Bank (2005). The 2005 world development indicators. International Bank for Reconstruction and Development.

Yang, G., \& Maskus, K. E. (1998). Intellectual property rights and licensing: An econometric investigation. Working Paper No. 98-34, Center for Economic Analysis, Department of Economics, University of Colorado at Boulder.

\section{Biography}

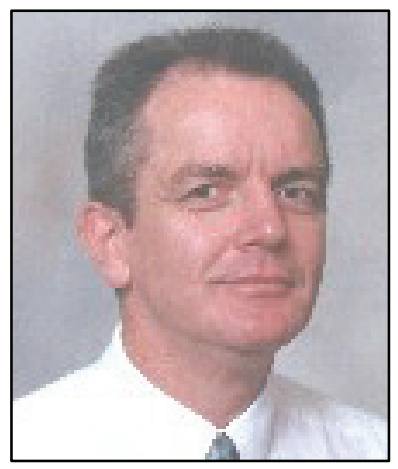

Dr Zlatko J Kovačić is an Associate Professor in the School of Information and Social Sciences at the Open Polytechnic of New Zealand. Zlatko has a varied academic background and research interests, ranging from core interests relating to IT careers, learning and teaching, to eCommerce, eLearning, time series analysis, multivariate analysis and Web (data) mining. His current research is focused on social and cultural aspects of information technology, on cognitive processes in distance education using computers and communications technologies and time series analysis of emerging financial markets. 


\section{Appendix: Literature review - Summary of Empirical Research}

\begin{tabular}{|c|c|c|c|c|}
\hline Study & $\begin{array}{l}\text { Number } \\
\text { of coun- } \\
\text { tries }\end{array}$ & $\begin{array}{l}\text { Dependent } \\
\text { variable }\end{array}$ & $\begin{array}{l}\text { Independent vari- } \\
\text { ables }\end{array}$ & Key findings \& comments \\
\hline $\begin{array}{l}\text { Ginarte \& } \\
\text { Park (1997) }\end{array}$ & $\begin{array}{l}110 \text { coun- } \\
\text { tries, pe- } \\
\text { riod } 1960- \\
1990\end{array}$ & $\begin{array}{l}\text { Patent right } \\
\text { index }\end{array}$ & $\begin{array}{l}\text { Real GDP per capita, } \\
\text { R\&D (\% of GDP), sec- } \\
\text { ondary school enroll- } \\
\text { ment rate, political } \\
\text { rights index, market } \\
\text { freedom index, openness } \\
\text { index (all variables ex- } \\
\text { cept the last one were } \\
\text { logged) }\end{array}$ & $\begin{array}{l}\text { Market freedom is a strong deter- } \\
\text { minant of patent protection level, } \\
\text { lagged R\&D investment rates are } \\
\text { also strong determinant of patent } \\
\text { protection for developed econo- } \\
\text { mies and lagged openness is } \\
\text { strong determinant for developing } \\
\text { countries. }\end{array}$ \\
\hline $\begin{array}{l}\text { Gopal \& } \\
\text { Sanders } \\
(1998)\end{array}$ & $\begin{array}{l}13 \text { groups } \\
\text { of coun- } \\
\text { tries in } \\
1995 \text { and } \\
1996\end{array}$ & Piracy rate & $\begin{array}{l}\text { Real GDP per capita, } \\
\text { domestic software mar- } \\
\text { ket size/GDP }\end{array}$ & $\begin{array}{l}\text { For every } \$ 1,000 \text { increase in GDP } \\
\text { there will be a } 1.3 \% \text { decrease in } \\
\text { piracy rates. There is an inflection } \\
\text { point at about } \$ 6,000 \text { where in- } \\
\text { come levels below the inflection } \\
\text { point exhibit a different relation- } \\
\text { ship with the piracy rates. }\end{array}$ \\
\hline $\begin{array}{l}\text { Yang \& Mas- } \\
\text { kus (1998) }\end{array}$ & $\begin{array}{l}26 \text { coun- } \\
\text { tries over } \\
\text { three years: } \\
1985,1990 \\
\text { and } 1995\end{array}$ & $\begin{array}{l}\text { Volume of } \\
\text { US licens- } \\
\text { ing receipts } \\
\text { from abroad }\end{array}$ & $\begin{array}{l}\text { Index of patent laws, } \\
\text { openness of the country, } \\
\text { population, real GDP } \\
\text { per capita and secondary } \\
\text { school enrolment rate. }\end{array}$ & $\begin{array}{l}\text { Fixed-effects and random-effects } \\
\text { estimation methods have been } \\
\text { used. Results suggested that US } \\
\text { receipts of unaffiliated royalties } \\
\text { and licensing fees are likely to be } \\
\text { higher with stronger IPRs and } \\
\text { higher per capita GDP level in the } \\
\text { technology recipient countries. } \\
\text { There is weak evidence that open- } \\
\text { ness to trade encourages export } \\
\text { trade in relation to licensing. }\end{array}$ \\
\hline $\begin{array}{l}\text { Gopal \& } \\
\text { Sanders } \\
(2000)\end{array}$ & $\begin{array}{l}65 \text { coun- } \\
\text { tries in } \\
1997\end{array}$ & Piracy rate & Real GDP per capita & $\begin{array}{l}\text { For every } \$ 1,000 \text { increase in GDP } \\
\text { there will be a } 1.3 \% \text { decrease in } \\
\text { piracy rates. There is an inflection } \\
\text { point at about } \$ 6,000 \text { where in- } \\
\text { come levels below the inflection } \\
\text { point exhibit a different relation- } \\
\text { ship with the piracy rates. }\end{array}$ \\
\hline $\begin{array}{l}\text { Husted } \\
(2000)\end{array}$ & $\begin{array}{l}39 \text { coun- } \\
\text { tries in } \\
1996\end{array}$ & Piracy rate & $\begin{array}{l}\text { Economic development, } \\
\text { income inequality, cul- } \\
\text { tural variables: power } \\
\text { distance, individualism, } \\
\text { masculinity and uncer- } \\
\text { tainty avoidance Confu- } \\
\text { cian dynamism }\end{array}$ & $\begin{array}{l}\text { Software piracy is significantly } \\
\text { related to GNP per capita, income } \\
\text { inequality and individualism }\end{array}$ \\
\hline
\end{tabular}




\begin{tabular}{|c|c|c|c|c|}
\hline Study & $\begin{array}{l}\text { Number } \\
\text { of coun- } \\
\text { tries }\end{array}$ & $\begin{array}{l}\text { Dependent } \\
\text { variable }\end{array}$ & $\begin{array}{l}\text { Independent vari- } \\
\text { ables }\end{array}$ & Key findings \& comments \\
\hline $\begin{array}{l}\text { Marron \& } \\
\text { Steel (2000) }\end{array}$ & $\begin{array}{l}77 \text { coun- } \\
\text { tries, pe- } \\
\text { riod 1994- } \\
1997\end{array}$ & $\begin{array}{l}\text { Average } \\
\text { piracy rate }\end{array}$ & $\begin{array}{l}\text { Gross domestic product } \\
\text { per capita, individual- } \\
\text { ism, institutions (Knack } \\
\text { and Keefer's composite } \\
\text { index), expenditures on } \\
\text { research and develop- } \\
\text { ment in GDP, education, }\end{array}$ & $\begin{array}{l}\text { Software piracy is related to GDP } \\
\text { per capita, individualism and insti- } \\
\text { tutions protecting contracts and } \\
\text { property. Though it is related to } \\
\text { education and high research and } \\
\text { development intensity, their im- } \\
\text { pact is weak when controlling for } \\
\text { economic, cultural and institu- } \\
\text { tional factors. }\end{array}$ \\
\hline $\begin{array}{l}\text { Hogenbirk \& } \\
\text { van Kranen- } \\
\text { burg (2001) }\end{array}$ & $\begin{array}{l}44 \text { coun- } \\
\text { tries in } \\
1999\end{array}$ & $\begin{array}{l}\text { Piracy rate } \\
\text { Revenue } \\
\text { loss } \\
\text { (log Reve- } \\
\text { nue loss) }\end{array}$ & $\begin{array}{l}\text { Domestic market size } \\
\text { (GDP), share of export } \\
\text { of goods and services in } \\
\text { GDP, share of high tech- } \\
\text { nology exports, number } \\
\text { of PC per } 1,000 \text { persons, } \\
\text { number of TV per } 1,000 \\
\text { persons, country credit- } \\
\text { worthiness rating and } \\
\text { country copyright pro- } \\
\text { tection system }\end{array}$ & $\begin{array}{l}\text { No relationship between GDP and } \\
\text { piracy rates. Strong copyright } \\
\text { protection and higher creditwor- } \\
\text { thiness result in lower piracy } \\
\text { rates. Mixed results were obtained } \\
\text { when PC and TV penetration vari- } \\
\text { ables were included. } \\
\text { Larger market size results in } \\
\text { higher losses, even if piracy rates } \\
\text { are relatively low. There are sig- } \\
\text { nificant differences in piracy } \\
\text { among separate regions in the } \\
\text { world. }\end{array}$ \\
\hline $\begin{array}{l}\text { Ronkainen \& } \\
\text { Guerrero- } \\
\text { Cusumano } \\
\text { (2001) }\end{array}$ & $\begin{array}{l}50 \text { coun- } \\
\text { tries, } 1997\end{array}$ & $\begin{array}{l}\text { Intellectual } \\
\text { property } \\
\text { violation } \\
\text { (software } \\
\text { piracy) }\end{array}$ & $\begin{array}{l}\text { Purchasing power pari- } \\
\text { ties, GDP, corruption } \\
\text { perceptions index, four } \\
\text { Hofstede's cultural con- } \\
\text { structs: power distance } \\
\text { index, individualism, } \\
\text { masculinity and uncer- } \\
\text { tainty avoidance index, } \\
\text { commitment to protec- } \\
\text { tion of intellectual prop- } \\
\text { erty rights (measured by } \\
\text { corruption index), trade } \\
\text { involvement. }\end{array}$ & $\begin{array}{l}\text { Purchasing power parities, corrup- } \\
\text { tion perceptions index individual- } \\
\text { ism and masculinity were found to } \\
\text { be significant in the final regres- } \\
\text { sion model estimated. }\end{array}$ \\
\hline $\begin{array}{l}\text { Andrés } \\
(2002)\end{array}$ & $\begin{array}{l}24 \text { Euro- } \\
\text { pean coun- } \\
\text { tries in the } \\
\text { year } 1994, \\
1997 \text { and } \\
2000\end{array}$ & Piracy rate & $\begin{array}{l}\text { GDP per capita and } \\
\text { strength of software } \\
\text { piracy }\end{array}$ & $\begin{array}{l}\text { Panel data models were estimated. } \\
\text { Both index of software protection } \\
\text { and income were significant } \\
\text { though the impact of software } \\
\text { protection was weaker in magni- } \\
\text { tude. }\end{array}$ \\
\hline
\end{tabular}




\begin{tabular}{|c|c|c|c|c|}
\hline Study & $\begin{array}{l}\text { Number } \\
\text { of coun- } \\
\text { tries }\end{array}$ & $\begin{array}{l}\text { Dependent } \\
\text { variable }\end{array}$ & $\begin{array}{l}\text { Independent vari- } \\
\text { ables }\end{array}$ & Key findings \& comments \\
\hline $\begin{array}{l}\text { Andrés } \\
(2003)\end{array}$ & $\begin{array}{l}24 \text { Euro- } \\
\text { pean coun- } \\
\text { tries in the } \\
\text { year } 1994, \\
1997 \text { and } \\
2000\end{array}$ & $\begin{array}{l}\text { Piracy rate } \\
\text { (lnPIRACY) }\end{array}$ & $\begin{array}{l}\text { Software protection, per } \\
\text { capita income - GDP per } \\
\text { capita } 1995 \text { US \$ } \\
\text { (lnGDPPC), scientific } \\
\text { infrastructure - R\&D } \\
\text { expenditures ( } \% \text { of } \\
\text { GDP), educational at- } \\
\text { tainment - average years } \\
\text { of schooling in popula- } \\
\text { tion }>25 \text { years. Freedom } \\
\text { Index - political rights } \\
\text { and civil liberties } \\
\text { As instrumental vari- } \\
\text { ables measure of quality } \\
\text { of bureaucracy and rule } \\
\text { of law were used. }\end{array}$ & $\begin{array}{l}\text { Software protection has a signifi- } \\
\text { cant negative effect on piracy rate. } \\
\text { Per capita income also has a nega- } \\
\text { tive effect. } \\
\text { Higher stock of human capital } \\
\text { leads to lower piracy rate. Free- } \\
\text { dom index has a negative effect } \\
\text { but the effect was positive when } \\
\text { R\&D expenditures variable was } \\
\text { included. However, none of these } \\
\text { three variables were significant. } \\
\text { Natural logarithm was used for } \\
\text { GDP because non-linear relation- } \\
\text { ship with piracy rate was ex- } \\
\text { pected. OLS and } 2 \text { SLS estimation } \\
\text { methods were used. }\end{array}$ \\
\hline Holm (2003) & $\begin{array}{l}75 \text { coun- } \\
\text { tries; in the } \\
\text { year } 1999\end{array}$ & Piracy rate & $\begin{array}{l}\text { Gross national income } \\
\text { (GNI) per capita and } \\
\text { rule of law }\end{array}$ & $\begin{array}{l}\text { Both GNI per capita and rule of } \\
\text { law variables were statistically } \\
\text { significant }\end{array}$ \\
\hline $\begin{array}{l}\text { Moores } \\
(2003)\end{array}$ & $\begin{array}{l}45 \text { coun- } \\
\text { tries, pe- } \\
\text { riod 1994- } \\
1998\end{array}$ & $\begin{array}{l}\text { Average } \\
\text { piracy rate }\end{array}$ & $\begin{array}{l}\text { Gross national income } \\
\text { (GNI) per capita and } \\
\text { Hofstede's cultural con- } \\
\text { structs: power distance } \\
\text { index, individualism, } \\
\text { masculinity and uncer- } \\
\text { tainty avoidance index. }\end{array}$ & $\begin{array}{l}\text { GNI and individualism were iden- } \\
\text { tified as variables with dominant } \\
\text { impact on software piracy rate by } \\
\text { using forward stepwise regression } \\
\text { analysis. }\end{array}$ \\
\hline $\begin{array}{l}\text { Papadopoulos } \\
\text { (2003) }\end{array}$ & $\begin{array}{l}84 \text { coun- } \\
\text { tries, } 1998\end{array}$ & $\begin{array}{l}\text { Piracy mar- } \\
\text { ket share }\end{array}$ & $\begin{array}{l}\text { International copyright } \\
\text { convention membership } \\
\text { and membership dura- } \\
\text { tion, IPR enforcement, } \\
\text { corruption in civil ser- } \\
\text { vice, expected profit, } \\
\text { affordability and the } \\
\text { balance of trade in } \\
\text { sound recording. }\end{array}$ & $\begin{array}{l}\text { Property right index is the most } \\
\text { significant variable. Other signifi- } \\
\text { cant variables are: corruption, } \\
\text { expected profit, size of the black } \\
\text { market operations, membership in } \\
\text { international copyright convention } \\
\text { and its duration and affordability } \\
\text { (price/earning ratio). }\end{array}$ \\
\hline $\begin{array}{l}\text { Bezman \& } \\
\text { Depken } \\
\text { (2004) }\end{array}$ & $\begin{array}{l}50 \text { United } \\
\text { States for } \\
\text { period } \\
1999-2001\end{array}$ & Piracy rate & $\begin{array}{l}\text { Gross state product per } \\
\text { capita (lnGDPPC), un- } \\
\text { employment, state tax } \\
\text { burden, and economic } \\
\text { freedom index. }\end{array}$ & $\begin{array}{l}\text { Income is negatively related to } \\
\text { piracy rate. Unemployment has } \\
\text { positive sign but the coefficient is } \\
\text { not statistically significant. State } \\
\text { tax burdens are negatively related } \\
\text { to software piracy, as is the eco- } \\
\text { nomic freedom of the state. }\end{array}$ \\
\hline
\end{tabular}




\begin{tabular}{|c|c|c|c|c|}
\hline Study & $\begin{array}{l}\text { Number } \\
\text { of coun- } \\
\text { tries }\end{array}$ & $\begin{array}{c}\text { Dependent } \\
\text { variable }\end{array}$ & $\begin{array}{l}\text { Independent vari- } \\
\text { ables }\end{array}$ & Key findings \& comments \\
\hline $\begin{array}{l}\text { Depken \& } \\
\text { Simmons } \\
\text { (2004) }\end{array}$ & $\begin{array}{l}65 \text { coun- } \\
\text { tries in the } \\
\text { year } 1994\end{array}$ & Piracy rate & $\begin{array}{l}\text { GDP per capita } 1995 \text { US } \\
\$ \text {, percentage trade with } \\
\text { USA, individualism } \\
\text { index, power distance } \\
\text { index, population in } \\
\text { labor force, literacy rate, } \\
\text { inflation rate }\end{array}$ & $\begin{array}{l}\text { GDP per capita has a significant } \\
\text { impact with negative sign. Greater } \\
\text { trade dependency with the USA } \\
\text { tends to reduce software piracy. } \\
\text { The percentage of population in- } \\
\text { cluded in the labor force has a } \\
\text { negative effect on piracy rate but } \\
\text { is not significant in all four re- } \\
\text { gression models estimated. Infla- } \\
\text { tion rate is statistically significant } \\
\text { suggesting that higher inflation } \\
\text { rates tend to reduce the amount of } \\
\text { software piracy. Education level } \\
\text { (literacy rate) is not significant but } \\
\text { the square of literacy has negative } \\
\text { and significant coefficient. Indi- } \\
\text { vidualism index is negative and } \\
\text { significant, the power distance } \\
\text { index yields conflicting results. } \\
\text { When literacy rate is included } \\
\text { power distance index is not sig- } \\
\text { nificant, otherwise it has positive } \\
\text { sign and significant. Also, the } \\
\text { interaction between individualism } \\
\text { and power distance has a positive } \\
\text { and significant impact on the pi- } \\
\text { racy rate. }\end{array}$ \\
\hline $\begin{array}{l}\text { Kyper et al. } \\
(2004)\end{array}$ & $\begin{array}{l}86 \text { coun- } \\
\text { tries, pe- } \\
\text { riod } 1991- \\
2001\end{array}$ & Piracy rate & $\begin{array}{l}\text { Economic variables: } \\
\text { Gross domestic product } \\
\text { (GDP), information } \\
\text { technology expendi- } \\
\text { tures, high-tech exports; } \\
\text { cultural variables: indi- } \\
\text { vidualism index and } \\
\text { power distance index } \\
\text { and temporal variable } \\
\text { (year) }\end{array}$ & $\begin{array}{l}\text { Based on all countries data GDP } \\
\text { has a strong effect as well as other } \\
\text { independent variables (including } \\
\text { individualism). However, when } \\
\text { the model (without GDP) was } \\
\text { estimated in two subsets of data } \\
\text { (countries with GDP above or } \\
\text { below } \$ 12,000 \text { ) power distance } \\
\text { index was insignificant. IT expen- } \\
\text { diture was ten time more influen- } \\
\text { tial on piracy among countries } \\
\text { with GDP } \$ 12,000 \text {, while the } \\
\text { high-tech exports were five times } \\
\text { more influential (countries with } \\
\text { GDP }>\$ 12,000 \text { ) and affects piracy } \\
\text { in the opposite direction. }\end{array}$ \\
\hline $\begin{array}{l}\text { Shin, Gopal, } \\
\text { Sanders \& } \\
\text { Whinston } \\
(2004) .\end{array}$ & $\begin{array}{l}49 \text { coun- } \\
\text { tries, } 1999\end{array}$ & Piracy rate & $\begin{array}{l}\text { GDP per capita, one of } \\
\text { Hofstede's cultural con- } \\
\text { structs, i.e. individual- } \\
\text { ism/collectivism. }\end{array}$ & $\begin{array}{l}\text { Results suggest negative relation- } \\
\text { ship between software piracy level } \\
\text { and GDP per capita and positive } \\
\text { relationship between software } \\
\text { piracy level and level of collectiv- } \\
\text { ism in countries. }\end{array}$ \\
\hline
\end{tabular}




\begin{tabular}{|c|c|c|c|c|}
\hline Study & $\begin{array}{c}\text { Number } \\
\text { of coun- } \\
\text { tries }\end{array}$ & $\begin{array}{l}\text { Dependent } \\
\text { variable }\end{array}$ & $\begin{array}{l}\text { Independent vari- } \\
\text { ables }\end{array}$ & Key findings \& comments \\
\hline $\begin{array}{l}\text { Bezman \& } \\
\text { Depken } \\
\text { (2005) }\end{array}$ & $\begin{array}{l}77 \text { coun- } \\
\text { tries in the } \\
\text { year } 1995 \text {, } \\
2000 \text { and } \\
2002\end{array}$ & $\begin{array}{l}\text { Piracy rate } \\
\\
\text { UN Human } \\
\text { Develop- } \\
\text { ment Index } \\
\text { (HDI) }\end{array}$ & $\begin{array}{l}\text { GDP per capita } 1995 \text { US } \\
\text { \$, economic freedom } \\
\text { index, inflation rate, } \\
\text { Internet users per } 1000 \\
\text { and GDP growth rate } \\
\text { Piracy rate, economic } \\
\text { freedom index and GDP } \\
\text { per capita. }\end{array}$ & $\begin{array}{l}\text { Instrumental variables panel esti- } \\
\text { mator is used. Piracy rate equation } \\
\text { was estimated in the first stage. } \\
\text { GDP per capita, economic free- } \\
\text { dom and the number of Internet } \\
\text { users are inversely related to pi- } \\
\text { racy rate. Inflation rate and GDP } \\
\text { growth are positively related to } \\
\text { piracy rate but they are not sig- } \\
\text { nificant. } \\
\text { Estimation results of economic } \\
\text { development equation showed tha } \\
\text { higher piracy rate is correlated } \\
\text { with a lower level of HDI. GDP } \\
\text { per capita and economic freedom } \\
\text { index are both positively corre- } \\
\text { lated with the HDI. }\end{array}$ \\
\hline $\begin{array}{l}\text { Shadlen, } \\
\text { Schrank \& } \\
\text { Kurtz (2005) }\end{array}$ & $\begin{array}{l}80 \text { coun- } \\
\text { tries, pe- } \\
\text { riod } 1994- \\
2002\end{array}$ & Piracy rate & $\begin{array}{l}\text { GDP per capita, number } \\
\text { of scientists and techni- } \\
\text { cians in R\&D per } 1,000, \\
\text { index of government } \\
\text { effectiveness, trade de- } \\
\text { pendence, and a set of } \\
\text { indicator variables re- } \\
\text { lated to WTO standards } \\
\text { and other multilateral, } \\
\text { bilateral and unilateral } \\
\text { treaties. }\end{array}$ & $\begin{array}{l}\text { Population-averaged panel data } \\
\text { models were used to explore the } \\
\text { relationship between piracy and } \\
\text { the relevant predictors. Study con- } \\
\text { firmed "standard" factors such as } \\
\text { GDP per capita and human capital } \\
\text { to be significant in explaining } \\
\text { piracy. Additionally it was dis- } \\
\text { covered that bilateral pressures to } \\
\text { protect intellectual property rights } \\
\text { stay significant in models control- } \\
\text { ling for multilateral treaties, GDP } \\
\text { and human capital, which suggest } \\
\text { that multilateral and bilateral pres- } \\
\text { sures are complementary. }\end{array}$ \\
\hline
\end{tabular}




\begin{tabular}{|c|c|c|c|c|}
\hline Study & $\begin{array}{c}\text { Number } \\
\text { of coun- } \\
\text { tries }\end{array}$ & $\begin{array}{l}\text { Dependent } \\
\text { variable }\end{array}$ & $\begin{array}{l}\text { Independent vari- } \\
\text { ables }\end{array}$ & Key findings \& comments \\
\hline $\begin{array}{l}\text { van Kranen- } \\
\text { burg \& Ho- } \\
\text { genbirk } \\
(2005)\end{array}$ & $\begin{array}{l}34-39 \\
\text { countries in } \\
1999\end{array}$ & $\begin{array}{l}\text { Piracy rate } \\
\text { and esti- } \\
\text { mated reve- } \\
\text { nue loss in } 4 \\
\text { US copy- } \\
\text { right-based } \\
\text { industries: } \\
\text { business } \\
\text { software } \\
\text { applications, } \\
\text { sound re- } \\
\text { cording and } \\
\text { musical } \\
\text { composi- } \\
\text { tions, mo- } \\
\text { tion pictures } \\
\text { and enter- } \\
\text { tainment } \\
\text { software } \\
\text { piracy }\end{array}$ & $\begin{array}{l}\text { Country's domestic mar- } \\
\text { ket size (GDP as proxy), } \\
\text { share of exports of } \\
\text { goods and services in } \\
\text { GDP, percentage of total } \\
\text { manufactured exports } \\
\text { made up by high- } \\
\text { technology products, } \\
\text { number of PCs and TVs } \\
\text { per } 1,000 \text { persons, coun- } \\
\text { try risk rating, copyright } \\
\text { protection system index. }\end{array}$ & $\begin{array}{l}\text { Ordinary least squares estimation } \\
\text { method was used. In all four in- } \\
\text { dustries low country risk resulted } \\
\text { in significantly lower piracy rate } \\
\text { (weak for entertainment software). } \\
\text { Penetration of PCs was not sig- } \\
\text { nificant while high density of TVs } \\
\text { in the country positively influ- } \\
\text { enced the motion picture piracy } \\
\text { rate. Strong copyright protection } \\
\text { systems have significant impact } \\
\text { on a piracy rate. No evidence was } \\
\text { found for the relation between } \\
\text { country's exports, technology } \\
\text { level and software piracy rate. } \\
\text { On the other side, when consider- } \\
\text { ing revenue losses due to piracy, } \\
\text { strong evidence of a positive in- } \\
\text { fluence of the market size on the } \\
\text { software piracy was found. The } \\
\text { results on country risk are con- } \\
\text { flicting (negative influence in case } \\
\text { of motion picture and positive in } \\
\text { case of business software). PCs } \\
\text { penetration has no influence on } \\
\text { revenue losses, while density of } \\
\text { TVs increases the estimated reve- } \\
\text { nue losses in motion picture in- } \\
\text { dustry. } \\
\text { In case of country's export de- } \\
\text { pendence indicator positive and } \\
\text { significant relation to revenue } \\
\text { losses in business software appli- } \\
\text { cation was found. The same rela- } \\
\text { tion was found in motion picture } \\
\text { industry when considering high- } \\
\text { technology exports. Finally, the } \\
\text { hypothesis that strong system of } \\
\text { copyright protection in the coun- } \\
\text { try would have positive impact on } \\
\text { the revenue losses was not sup- } \\
\text { ported. }\end{array}$ \\
\hline
\end{tabular}




\begin{tabular}{|c|c|c|c|c|}
\hline Study & $\begin{array}{c}\text { Number } \\
\text { of coun- } \\
\text { tries }\end{array}$ & $\begin{array}{l}\text { Dependent } \\
\text { variable }\end{array}$ & $\begin{array}{l}\text { Independent vari- } \\
\text { ables }\end{array}$ & Key findings \& comments \\
\hline $\begin{array}{l}\text { Bagchi, Kirs } \\
\text { \& Cherveny } \\
\text { (2006) }\end{array}$ & $\begin{array}{l}37 \text { coun- } \\
\text { tries in the } \\
\text { year } 1996 \text {, } \\
2001 \text { and } \\
2003\end{array}$ & Piracy rate & $\begin{array}{l}\text { GDP per capita, IT in- } \\
\text { frastructure, Internet } \\
\text { use, trade regulations } \\
\text { laws related to IT, cor- } \\
\text { ruption, and two of } \\
\text { Hofstede's cultural con- } \\
\text { structs, i.e. individual- } \\
\text { ism/collectivism and } \\
\text { uncertainty avoidance. }\end{array}$ & $\begin{array}{l}\text { Partial least squares regression } \\
\text { was applied to data. Overall GDP } \\
\text { per capita was partly significant (- } \\
\text { ) as well as IT infrastructure (-), } \\
\text { trade regulation (-), laws related to } \\
\text { IT (-) and uncertainty avoidance (- } \\
\text { ). Corruption (-) and collectivism } \\
\text { (+) were significant while Internet } \\
\text { use was not. }\end{array}$ \\
\hline $\begin{array}{l}\text { Ki, Chang \& } \\
\text { Khang (2006) }\end{array}$ & $\begin{array}{l}58 \text { coun- } \\
\text { tries in } \\
\text { period } \\
1996-2002\end{array}$ & $\begin{array}{l}\text { Music pi- } \\
\text { racy rate }\end{array}$ & $\begin{array}{l}\text { GDP per capita, income } \\
\text { inequality (Gini index), } \\
\text { individualism, education } \\
\text { level, intellectual prop- } \\
\text { erty protection, CD } \\
\text { price, market size of } \\
\text { music piracy. }\end{array}$ & $\begin{array}{l}\text { Regression and path analysis were } \\
\text { used. GDP per capita and Gini } \\
\text { index were significant (-) at the } \\
\text { beginning of period but not in } \\
\text { later years. Countries with stricter } \\
\text { intellectual property protection } \\
\text { enforcement and the bigger music } \\
\text { market have lower music piracy } \\
\text { rate. Finally, the cultural construct } \\
\text { individualism, education level and } \\
\text { CD price were not significant. }\end{array}$ \\
\hline
\end{tabular}

